\title{
Can Corporate Social Responsibility resolve the sanitation question in developing Asian countries?
}

\author{
Kumudini Abeysuriya, Cynthia Mitchell and Stuart White \\ Institute for Sustainable Futures, University of Technology Sydney, Australia
}

\begin{abstract}
The existing state of sanitation in developing Asian countries fails to deliver a level of service that is adequate for meeting the human right to a standard of living consistent with dignity and health, or for sustaining the capacity for future generations to have access to clean water resources and healthy ecosystems. We argue that translating the current neo-centralised technologies and institutional arrangements mainstreamed by industrialised countries would not resolve the problem in the context of developing countries. Instead it is necessary to 'leap frog' to the emerging technological and institutional arrangements that are responsive to current needs and contexts and to potential risks. The sustainability focus and often decentralised technologies of this emergent stage in sanitation present many opportunities for new actors to enter the urban sanitation industry. At the same time, there are many barriers to entry, particularly from the perspective of conventional business management focused on increasing shareholder value.

We propose that perspectives from the corporate social responsibility discourse have the potential to provide both the 'pull' for seizing the business opportunity for profit while serving social needs, and the 'push' to overcome the barriers in order to serve a wider social purpose for corporations. The wealth of nations, at least as reported in ubiquitous GDP terms, has greatly increased through the activities of corporations driven by a profit motive; but the increased poverty, injustice and ecosystem degradation that has resulted from economic activity suggests that corporations perhaps ought to have regard for broader concerns beyond shareholder value. We explore how the alternative relational view of a corporation, as a metaphorical person within society who adopts a moral code consistent with both Buddhist economics and Adam Smith's philosophy, may facilitate profitable corporations that provide better economic, ecological and social outcomes in serving the need for sustainable sanitation services in developing Asian countries.
\end{abstract}

\section{INTRODUCTION: THE CONUNDRUM OF URBAN SANITATION IN DEVELOPING ASIAN COUNTRIES}

The Universal Declaration on Human Rights is a declaration of the inherent dignity and inalienable rights of all humans, including the right to a standard of living adequate for health and well-being (UN 1948, Article 25). Access to adequate sanitation, as a facilitator of dignity, public health and amenity, is accordingly recognised as a fundamental human right, essential for the long term well being of society and ecosystems, and therefore, for sustainability. This recognition has led to international efforts to rectify the 'violation' of this human right, first by the declaration of the 1980s as the Drinking Water Supply and Sanitation Decade which increased access to millions in developing countries, and now, the Millennium Development Goals with their 
'environmental sustainability' target to reduce the proportion of people without access to safe drinking water and basic sanitation by half, by 2015 (World Bank Group 2004).

For cities in developing Asian countries in particular, the provision of adequate sanitation poses a conundrum. Water and sanitation infrastructure has not been able to keep up with the rapid population growth in cities (Biswas et al. 2004); cash strapped governments are faced with competing infrastructure investment needs; current levels of international aid for infrastructure to Asian countries is likely to decrease as addressing the crises of African countries receives more urgent priority (Evans 2005, p. 11); and attempts to attract private sector investment are hampered by the disjunct between the high capital cost of infrastructures and the public's low valuation of sanitation and therefore low willingness to pay (Kessides 2004, p. 222; Mulenga \& Fawcett 2003; SIWI 2004, p. 21).

The purpose of this paper is to contribute to the resolution of this conundrum. Our argument has two parallel strands which are presented in separate sections below. The first, in Section 2, examines sanitation trends in industrialised countries to demonstrate that emerging ways of thinking open up new and different opportunities for the private sector to participate in this sector, especially in developing Asian countries. The second strand, in Section 3, explores moral arguments founded on Buddhist economics and the corporate social responsibility discourse, as a means of complementing and reinforcing policy incentives to encourage private sector players to take up these opportunities.

\section{TRENDS AND OPPORTUNITIES FOR PRIVATE SECTOR PARTICIPATION IN SANITATION}

The progression of sanitation in industrialised countries over the last century has had a great influence on the sanitation policies of developing countries. The concept of 'development' is widely interpreted as implying that developing countries would follow the development path forged by industrialised countries, with the assistance of these 'more developed' countries (McGranahan et al. 2001, p. 3). This may be a reflection of the post-World War II notion of 'modernization theory' that postulates that "industrial development followed a coherent pattern of growth, and would in time produce certain uniform social and political structures across different countries and cultures," (Alvey 2003, quoting from Fukuyama 1992). For developing Asian countries, it is therefore useful to first examine the evolution of urban sanitation infrastructures in industrialised countries, to question whether it is an appropriate path for developing countries to follow in current contexts.

\subsection{Evolution of urban sanitation in industrialised countries}

In our analysis of the evolution of urban sanitation practices in the cities of industrialised countries, we identify a trend consisting of four stages. The first stage had unmanaged sanitary arrangements, early in the industrial revolution, as unplanned cities sprang up around manufacturing centres. This period was characterised by households making their own sanitation arrangements and by high levels of localised pollution and poor public health. These conditions led to the 'sanitation revolution' in the mid-1800s (Goddard 1996) and to the next stage, of centralised infrastructure. This saw the construction of 
large scale piped infrastructures that brought safe water supplies into cities, and transported water-borne human waste out of cities, which addressed both the urban pollution and public health issues, as well as fire protection and flood mitigation (through stormwater systems), and underpinned the development of modern day cities. The transport of sewage shifted the environmental burden to the point of discharge, with potential feedbacks to human populations. In response, the stage that followed was based on modifying and refining the centralised stage to meet a new priority for reducing negative environmental impacts, which we therefore name the neo-centralised stage. The early neo-centralised stage focused on environmental problems as experienced by people, and addressed these through moves such as constructing long outfalls to release sewage far from the coastline into the ocean rather than rivers. The more recent stages of this neo-centralised period have focused more squarely on alleviating sanitation's impacts on the environment, and led to the progression of end-of-pipe wastewater treatment to advanced treatment and re-use in dual reticulation networks. We see present infrastructure developments in industrialised countries as being at a junction between the late neo-centralised stage and the embryonic fourth or emergent stage. This emergent stage is driven by concerns for sustainability, and is so named for its associations with systems thinking that sustainability necessitates, as well as for its descriptiveness as a fresh approach coming into existence. It reverts to a more 'first principles' approach towards urban water and sanitation services that is responsive and adaptive to current needs and contexts, contexts that differ significantly from those that led to the dominant centralised paradigm. The emergent stage takes an integrative approach to urban water services (water supply, sanitation, stormwater management), and responds to system limits and risks. The emergent stage for urban sanitation includes distributed wastewater treatment and reuse at different scales, and integration with other urban infrastructure services - water supply, stormwater management, energy, waste management and transport. It reflects a fundamentally different way of thinking in relation to urban water and sanitation service provision, replacing a 'predict and provide' approach with an 'enduse, integrated resource planning approach’ (Mitchell \& Campbell 2004). This way of thinking promotes the evaluation of diverse technological options of different scales on an equal basis with the emphasis on matching the service with the needs in context, in contrast to centralised and neo-centralised thinking that approaches the problem with a largely predetermined solution.

The historical stages for institutional arrangements for sanitation are closely linked to both the corresponding technological stages and the prevailing economic paradigms. The unmanaged stage corresponded with non-existent or weak institutional arrangements in the early industrialising cities. Centralised physical infrastructure was owned and operated by centralised governments through centralised planning and management under a public service ethos (Bakker 2001). The environmental concerns of the neo-centralised stage have added the involvement of institutions such as environmental protection authorities and economic regulators and the definition of performance standards. As market economics began to dominate in other jurisdictions, infrastructure services like water and sanitation were still largely considered areas of market failure - a view also taken by the so-called father of modern economics Adam Smith, who wrote that the sovereign should take responsibility for "erecting and maintaining certain public works and certain public institutions which it can never be for the interest of any individual, or 
small number of individuals, to erect and maintain; because the profit could never repay the expence to any individual or small number of individuals, though it may frequently do much more than repay it to a great society” (A. Smith 1904, IV. IX. 51).

However, the increasing influence of neoclassical economic ideology under the leadership of Reagan and Thatcher in the 1980s, led to a shift in perception about the appropriate role of government in utility services (Roy 1999, p. 18). The contestable assumption that state-provided monopoly infrastructure services are necessarily less efficient than services provided by companies (Estache \& Rossi 2002; Renzetti \& Dupont 2003; Seppälä et al. 2001), led to new institutional arrangements; ownership and/or control of public infrastructures were transferred to corporatised or private institutions to be operated and maintained on market-based principles for economic efficiency, with government taking on a regulatory and oversight role to correct for 'market failures' (Bakker 2001). The neo-centralised stage of sanitation in industrialised countries thus includes institutional arrangements with varying degrees of corporatisation and privatisation. The emergent stage, which includes a range of distributed and decentralised technologies at various scales, creates diverse business opportunities for products and services, involving many types of companies, organisations and institutions (Berry et al. 2004). This early in the emergent stage, there is no clear or explicit vision for the institutional arrangements; the examples of emergent practices are generally managed at pilot projects on an estate scale under existing institutional arrangements (Czemiel 2000; Fittschen \& Niemczynowicz 1997; Hanaeus et al. 1997; Otterpohl et al. 1997; Peter-Fröhlich et al. 2003), with government performing a regulatory and oversight role. We anticipate that with its commitment to sustainability ideals, the emergent stage model for institutional arrangements would involve cooperation between the private sector, government and society, and would pay attention to issues of equity in distribution and allocation in the spirit of ecological economics.

\subsection{Developing Asian countries: status and aspirations}

The stages in sanitation discussed above may be considered a taxonomy for classifying the different technological and institutional arrangements around the world. For cities in developing Asian countries, we broadly locate technological arrangements for sanitation at a stage between unmanaged and centralised. Many cities in countries such as Sri Lanka, India, Thailand and Indonesia typically have some areas that are not serviced with any infrastructures, where very low-income populations live. A majority of urban households are served by onsite systems; poor institutional arrangements for management and maintenance have made onsite systems notorious for their high rates of failure or malfunction, in both industrialised and developing countries (NDWRCDP 2004). In some cases there is also some limited centralised piped sewerage; these are generally aging and often dilapidated, so that although centralised by design, the practice tends towards the unmanaged stage.

Institutionally, there is a disjunction between policy and practice. Many developing Asian countries may be placed near the neo-centralised stage in terms of institutional policy for sanitation arrangements which often include definition of standards for environmental protection corresponding to world's best practice. However, the implementation of policy 
is weak and uncoordinated, partly due to the poor state of the technological infrastructure and lack of sufficient funds.

The aspirations of decision makers in these countries appear to be the centralised stage of technology and the neo-centralised stage of institution arrangements. Domestic governments and the international aid industry promote centralised technology as a long term goal (for example, see NWSDB 2001). At the same time, these countries are implementing institutional reforms for water and sanitation infrastructure services, aimed at shifting to the neo-centralised institutional stage conducive to private sector participation. This move is largely driven by prompting and pressure from multilateral financial institutions (Grusky \& Fiil-Flynn 2004; Kessides 2004), who see the current market-based model of industrialised countries as the one for developing countries to emulate, consistent with the general assumptions about 'development' noted earlier.

The shift from centralised to neo-centralised institutional arrangements, as it is being engineered, presents an intractable situation for developing Asian countries. The shift for industrialised countries was underpinned by the existence of extensive publicly funded capital infrastructure which could be transferred to corporate entities to operate and manage. With this core element missing in developing countries, the expectation for the private sector to invest in costly centralised infrastructure and manage it according to market principles appears to be an insurmountable challenge. This is articulated as follows:

"The private sector does not generally find investment in water infrastructure an attractive proposition because the risks involved are too great, pay-back periods are too long, and many projects are financially not viable in that they are unable to sustain the level of returns needed by the private sector," since "few customers are in a position to pay [the necessary] high tariffs”. (SIWI 2004, pp. 9, 21)

Therefore, a progression toward the ideal that appears dominant in many industrialised countries, where centralised or neo-centralised technical systems are operated on commercial market principles, is not possible in developing Asian countries. Many argue that it is also not desirable, because industrialised countries themselves would design and operate urban sanitation very differently, if they were in a position to design it afresh based on current information (Brown 2003; Feacham et al. 1983; Lawson 2003).

For sustainability in developing Asian countries, a leap directly to the emergent stage, for both technology and institutional arrangements, may be both necessary and possible. We see this as positive, since we see emergent institutional arrangements involving cooperation between government, the private sector and society, with the private sector providing those segments of services that it may profitably provide. We posit that the emergent stage, particularly the distributed technologies it includes, create a range of new opportunities for the private sector.

\subsection{Business opportunities in sanitation in the emerging era}

The private sector generally enters markets when they see: (a) a potential market in a need to be fulfilled, and (b) a way to meet the need and generate a profit. We have 
highlighted the need for resolution in urban sanitation in developing Asian countries, which thus identifies a potential market. We will next explore the business opportunity or the potential for profit. We have identified elsewhere (Abeysuriya et al. 2005), that the emerging sustainability drivers re-define sanitation as a multi-faceted and productoriented service focused on reuse and recycling, delivering benefits such as agricultural nutrients and energy in addition to the service of human waste removal, and creating opportunities for a diverse range of actors. This function of sanitation is characteristic of the emergent stage that creates opportunities for many types of companies, organisations and institutions to offer products and services at many scales.

We limit our discussion of business opportunities to the distributed or decentralised services sector, because it invites new actors to enter the market. We note that emergent thinking may identify centralised large scale technologies as the appropriate choice for some contexts, so that existing markets for services and ancilliary products and services would continue.

We identify and elucidate three elements to the business opportunity in distributed services - the potential for market growth, opportunities for new products and services, and improvement on the existing service provision modes (Berry et al. 2004).

Potential for market growth:

Distributed infrastructure services for other utilities such as electricity and information and communication technology (ICT) are already growth industries (Gas Research Institute 1999; Jones \& Petrie 2000), with distributed water supply markets at its early stages (Berry et al. 2004). These have spawned a range of new technologies and service industries and continue to gain maturity as a services market. The distributed wastewater industry is in its embryonic stages, but identified as an important growth market in industrialised countries in North America, Europe and Australasia, supported by initiatives such as the National Decentralized Water Resources Capacity Development Project in the USA (NDWRCDP 2004) and many pilot and estate scale examples (Dietzmann \& Gross 2003; West 2003).

Opportunity for new products and services:

The emergent era brings opportunities for the participation of many actors in an industry with a 'retail and service' focus. The distributed infrastructure technologies and services require designers, component manufacturers, component importers, manufacturers, assemblers, installers, managers, maintenance and repair personnel. The associated efficiency technologies and services require a similar range of agents for designing, installing and maintaining retrofits as well as auditors and monitoring services. The reuse and recycling focus brings another group of actors to provide the services for processing biosolids, transporting and distributing agricultural nutrients, and producing energy, including equipment manufacturers, health and safety personnel, distributed energy service providers, labour contractors and others. Finally the emergent era can attract new investors such as ethical investment funds to enter this arena. 
Improvement on the existing service provision modes:

Distributed, intermediate scale sanitation systems are generally less resource intensive and have lower environmental impacts, and are regarded as better able to meet broad sustainability criteria than centralised systems (Lens et al. 2001; Newman 2001). Recent Australian studies show that decentralised systems for densely populated areas can be as cost effective as conventional systems that are commonly associated with economies of scale, when evaluated on the basis of whole of society costs or life cycle costs, and the benefits from effluent re-use are included for integrated water supply systems (Fane \& White 2001; Mitchell \& White 2003). A German study (Peter-Fröhlich et al. 2003) concludes that decentralised systems that include nutrient recycling and energy generation can cost less than conventional sewerage services that connect to existing centralised infrastructure. Failure risk from distributed systems is decreased, since the consequences of failure are limited to smaller geographical areas rather than causing collapse of the whole system (Wilderer \& Schreff 2000). Shorter lead times between planning and commissioning, lower financial risks, and increased employment opportunities are amongst other advantages cited (Lovins 2002; Pinkham et al. 2004). The emergent stage, for both distributed and centralised technological configurations, present possibilities for resource reuse, energy generation and recycling, which also offer benefits in terms of avoided imports of fertilizer and fossil fuels and their attendant environmental impacts.

The lack of extensive investment in centralised sanitation infrastructure in developing Asian countries gives them a greater opportunity to consider distributed options, compared to industrialised countries which are committed to maintain their enormous investments and sunk costs in centralised and neo-centralised infrastructures.

\subsection{Surmounting the barriers to taking up the business opportunities}

We have argued earlier that governments in developing Asian countries will have little capacity to provide services without assistance from the private sector if external aid is unavailable. We see the entry of the private sector into this market as a key to facilitating the necessary 'leap frogging' of developing Asian countries into the emergent era. We have indicated new business opportunities for private sector participation in the distributed services of the emergent stage, in addition to opportunities that currently exist for public-private partnerships in larger scale infrastructure services. However, the presence of barriers means that opportunities alone are insufficient incentive for attracting the required levels of private investment in sanitation.

There are significant barriers to the creation of and participation in an emergent era sanitation industry. Current social norms reflect a phobia towards discussing or confronting our own defecations, which is an obstacle to perceiving sanitation as a business opportunity. While there may be certain first-mover advantages, there are inherent risks in entering a brand new market. There is a paucity of data to base estimates of costs and potential profits outside of pilot-scale examples (Peter-Fröhlich et al. 2003). 
Investors regard infrastructure investments in general (Flyvbjerg et al. 2002, p. 78), and in developing countries in particular, as risky, and generally expect a rate of return of $20 \%$ or more on investments (Flyvbjerg et al. 2002; SIWI 2004). At the same time, it is common for governments, in both industrialised and developing countries, to underwrite private investment in infrastructure projects that has often resulted in situations where the public has had to bear a much higher cost for the investment than if the government itself had invested in them (Flyvbjerg et al. 2002; Shofiani \& Gustafsson 2004). This has contributed to distrust and intense public opposition to private sector service providers in the water sector (Gutierrez et al. 2003; Lobina \& Hall 1999).

What will it take to surmount the barriers and achieve the emergent stage in urban sanitation? It requires a combination of 'pull' factors that act as attractors or incentives for achieving the desired change, and 'push' factors that can drive the industry over the perceived barriers. The business opportunities described earlier represent 'pull' factors. Commonly, 'push' factors are provided through external interventions such as government legislation or loan conditions. While these interventions are partly present, they have not been sufficient to effect the required changes. The urgency with which sanitation needs resolution means that we should draw on all other available means for creating the necessary 'push' factors. In this paper we therefore turn to seeking 'push' factors that are more internal, to motivate the private sector to appropriately enter the solution space of this problem through moral arguments. We have identified the corporate social responsibility discourse as a potential line to follow, because it has been a motivating force for questioning some of the fundamental assumptions that form the basis for business practice. In what follows, we examine the relationship of corporations with society, and explore a moral framework to surmount the barriers. This framework calls corporations to action that deserves and earns public trust, beyond simply acting within the law.

\section{LOWERING THE BARRIERS TO PRIVATE SECTOR PARTICIPATION IN SANITATION: HOW MIGHT CORPORATE SOCIAL RESPONSIBILITY HELP?}

The corporate social responsibility discourse is of relatively recent origin, although most large corporations have always included some aspects of caring social activity within their management practices (Wilson 2001). There are many understandings of what corporate social responsibility means, resulting in a spectrum of motivations, with diverse positions taken and a number of alternative labels including socially responsible investment (SRI), corporate engagement with communities (CE) and corporate community involvement (CCI) and several others (Roy 1999; Weiser \& Zadek 2000). In this paper, we use the term CSR to loosely refer to all of these concepts, defined by their common purpose for facilitating the move towards a socially and ecologically sustainable future through voluntary business activities. We will henceforth refer to all private business entities as corporations, noting that these include an array of different legal and operating structures. 
The conversations around CSR have taken place in a context where CSR is viewed as the 'missing link' in resolving the disjunction between economic growth under market economics and its negative consequences (Freeman \& Liedtka 1991). A growing body of research suggests that capitalism, industrialisation, globalisation and market economics may have been carried too far, with too much emphasis on economic development based on growth in material consumption, and not enough attention on ecological limits or social constraints, that has resulted in increased poverty, injustice, and ecosystem degradation as a consequence of economic development (Daly 1990; Hamilton 2003; Saul 2005; J.W. Smith et al. 1999). International organisations, society, and corporations themselves, are increasingly seeing a role for corporations in mitigating the negative consequences of economic development and in aiding sustainable development (J. Nelson \& Prescott 2003; SIWI 2002; Wilson 2001).

There are many issues debated within the CSR discourse (Weiser \& Zadek 2000): we identify two of relevance here. The first relates to the answer to the question, 'to whom does a corporation owe its primary responsibility?' At one extreme of the range of possible answers, it is argued that shareholders own the corporation, and its managers are employed expressly for the purpose of maximising the value for them; it is the fiduciary duty of corporations to maximise value for its shareholders (Friedman 1970; Porter \& Kramer 2002). At the other extreme it is argued that the success of the corporation crucially depends on the contributions from other stakeholders - employees, suppliers, customers and others who have something at stake; therefore maximising value for all its stakeholders ought to be the corporate priority. Some see the creation of value for these wider stakeholders as the means by which shareholder value is created (Johnson \& Johnson undated). The debate is fuelled by the recent wave of downsizing and shedding of employees as a mechanism for increasing short term shareholder value (Kennedy 2000; Lazonick \& O'Sullivan 2000), bringing the interests of shareholders and other stakeholders directly into conflict. The shareholders in this context are perceived as 'pitted against' the other stakeholders, creating winners and losers.

The second relates to the answer to the question, 'to what extent should a corporation expect to benefit from its CSR activities?' Early in the discourse, Friedman (1970) argued that engagement in CSR amounts to giving away shareholders' money, which is beyond the mandate given to managers. This reflects an interpretation of CSR as something equivalent to corporate altruism which returns no tangible benefit to a corporation. Thus he argues that CSR investments that benefit a corporation, and are therefore justifiable from self interest, may be fraudulent or "hypocritical window-dressing"(Friedman 1970). More recently, others have taken the position that CSR should be an element of good business practice that strategically chooses ways to benefit both society and the corporation (Porter \& Kramer 2002), driven by a sense of 'enlightened self interest'(UN 2005). Consensus appears to be building around the latter position as the way to ensure that corporations take CSR seriously and remain committed to it for the long term (Roy 1999; SustainAbility 2004).

A shared understanding of the relationship between corporations and wider society offers a point of resolution of the above issues, which we explore in the next section. The debate reflects different perspectives on this relationship. At one end of the spectrum, 
neoclassical economic ideology sees a profit-maximising corporation as isolated and in competition with other corporations, with government and with the labour force (Bowie 1991). At the other end of the spectrum is the stakeholder view of a corporation, as a network of relationships and stakeholder interests - of managers, other employees, shareholders, customers, suppliers, local communities, government regulators and legislators, political groups and activists (Donaldson \& Preston 1995; Freeman \& Liedtka

1991; J.A. Nelson 2004; Söderbaum 2003). The former view supports the pursuit of the sole objective of increasing shareholder wealth, assuming that benefits for society as a whole would follow through the action of Adam Smith's famous metaphorical 'invisible hand'. Lazonick and O'Sullivan (2000) argue that this is not borne out empirically; the maximization of shareholder value as the sole driver of corporations has come at the cost of national prosperity in the USA. The perspective of corporations as co-constituents of the network of relationships, is promoted as one that will facilitate the necessary shifts in thinking needed for sustainability (Söderbaum 2003). We adopt this latter view, which we explore further in the following section.

\subsection{A moral framework for a corporation as a relational metaphorical person}

In society, relationships are fostered within a framework of social and moral codes that underpin social norms that dictate the behavior of individuals in society. Social norms extend behaviors beyond the minimum required by law, and are essential for protecting the social fabric and sharing resources without high enforcement costs. Dasgupta (1997, p. 12) notes that social norms are "self-enforcing behavioural strategies" which are "a way the rule could be enforced without the community's having to rely on the coercive powers of a higher authority (for example, the state)." It is appropriate that legal systems should not stipulate social behaviors beyond a minimum necessary for the orderly functioning of society. More exacting legal stipulations are likely to represent the ideals of particular power groups, and their enforcement is likely to be oppressive, whereas the minimum requirements are more likely to overlap the diverse ideals of wider society. A gap between what is legally required and socially desired preserves natural liberties; it allows individuals the 'freedom to offend' and earn social censure, or to act with benevolence and earn social esteem. In this section we propose that a moral code for corporations could elicit performance from corporations that better reflect their coconstituency in the relational network of society, than the minimum required by law.

Corporations' law treats a corporation as a metaphorical person with rights that correspond to those of real people, such as the right to autonomy and economic freedom (Dunn 1991). Bakan (2005) suggests that the metaphorical person that is a corporation, when it sees its sole purpose to be serving the financial interests of its shareholders, may be inclined to behave in ways comparable to a pathological psychopath: being singularly self- interested, manipulative, lacking empathy and disregarding social obligations. Corporate conduct that Bakan likens to psychopathy represents a disregard for the moral codes and behavioral norms of society, which suggests the perpetrator's sense of disconnection from other members of society. We argue that corporations' law reinforces this disconnection and facilitates the metaphorical person to limit its moral responsibility to simply abiding by the law. The legal frameworks treat a corporation as quite separate 
even from its managers (Dunn 1991; Velasquez 2003); although it is the managers who drive a corporation's activities and therefore define its character, legal safeguards allow them not to be held responsible for this character. Since a corporation itself lacks the intentionality to be morally responsible for its actions (Velasquez 2003), the law facilitates the moral expectations from this metaphorical person to be set lower than what is expected of real people in society. Thus society appears to tolerate behaviours from corporations that would be unacceptable from real people.

In the stakeholder view of a corporation, this metaphorical person is in relationship with other members of society. Since the legal frameworks do not adequately acknowledge this connectivity, we argue that behavioral norms based on a moral code would be needed to foster this relationship. What moral code might be applied to this metaphorical person as a member of a sustainable society, which would also be consistent with a corporation's need to remain financially viable?

We have identified Buddhist economics as a potential moral framework for corporations as metaphorical persons. 'Buddhist economics' refers to the collective teachings on economics interspersed within the Buddha's teachings, largely relating to 'right livelihood' (Daniels 2003; Payutto 1992; Schumacher 1973). This choice should, perhaps, not be surprising, because Buddhism is described as a moral philosophy that prescribes a 'middle way' that avoids both extremes in self-indulgence and in selfmortification (Rahula 1996, p. 45). It actively encourages seeking and possessing material wealth within certain ethical boundaries (Payutto 1992). Interestingly, there are several consistencies between a Buddhist economy and the wealthy society that Adam Smith envisaged - though again, perhaps, this should not be surprising when considering the likely influence of Smith's role as professor of moral philosophy on his ideas on economics (Alvey 2000).

We see a sustainable society as a necessarily 'wealthy' society, in that it is fair and just and meets human rights including rights to a standard of dignified living - which requires meeting socio-political and material needs using economic resources. Material welfare has a moral purpose in Buddhist economics, as the necessary precondition that enables the pursuit of higher spiritual goals. Therefore poverty is discouraged and the possession of wealth is praised (Payutto 1992). The ethical basis for possessing wealth originates in the karmic law of cause and effect that links all things in an interacting chain (Payutto 1992; Rahula 1996). This view overlaps with the systems perspective that characterises the sustainability discourse (Peet 1992, p. 78), which Buddhism extends by including mind and intent into the system. Accordingly in the Buddhist economic system, the ethical quality of intentions and actions define the outcomes that result, so that ends can never justify the means. This sets the ethical boundaries to the seeking and possession of wealth. Firstly, wealth should be acquired through ethical methods and with 'good' intentions behind them; second, wealth should be used to improve the welfare of oneself and others without causing any harm; and third, wealth should be possessed without mental attachment, so its holder is not enslaved by it, nor under an illusion that it may be an end in itself (Payutto 1992). 
Individual wealth is meant to serve a greater societal purpose. Payutto (1992) interprets the Buddhist teaching thus: "When the wealth of a virtuous person grows, other people stand to gain"... and "although it belongs to one person, it is as if it belonged to the whole community”. Alvey (2000) points out that Adam Smith similarly connected a moral purpose to the wealth of individuals for the improvement of nations. Smith stated that it is wealth founded on "private frugality and good conduct of individuals... [that] ...maintained the progress of England towards opulence and improvement", and preventing abject poverty from driving people to the immorality of "abandoning their infants, their old people, and those afflicted with lingering diseases" (A. Smith 1904, II.III.36 and I.I.4). Alvey (2000) argues that Smith never advocated unfettered self interest, but rather, a system of natural liberty underpinned by morality. The societal purpose of wealth was articulated more radically by millionaire philanthropist Andrew Carnegie, one of the originators of the notion of CSR, that wealthy individuals and businesses should see themselves as stewards of their property, held in trust for the rest of society (Freeman \& Liedtka 1991):

"Holding it in trust for society as a whole, they can use it for any purpose society deems legitimate. However, it is also a function of business to multiply society's wealth by increasing its own through prudent investments of the resources that it is caretaking." (as quoted by Freeman \& Liedtka 1991)

How may a corporation achieve this societal purpose without bankrupting itself? Buddhist economics instructs the individual (extended here to the metaphorical corporate person) on how to serve this purpose through allocating one's income to each of the following areas in accordance with one's means (Payutto 1992; Rahula 1996):

- Spend a portion for meeting the needs of one's self and dependents (make returns to shareholders, pay fair wages to employees);

- Spend a portion generously on friends (invest in serving the interests of stakeholders, others who have contributed to the success of the corporation, directly or indirectly);

- Re-invest a portion to create more wealth (make prudent investments to ensure continued success in business); and

- Spend a portion on good works to increase well being in society (engage in philanthropic works).

The relational stakeholder view of corporations is consistent with the Buddhist view of humans' (and metaphorical person's) existence within the simultaneous spheres of the individual, society and the environment (Payutto 1992). This view is reinforced by Adam Smith thus:

"Man, according to the Stoics, ought to regard himself, not as something separated and detached, but as a citizen of the world, a member of the vast commonwealth of nature. To the interest of this great community, he ought at all times to be willing that his own little interest should be sacrificed” (A. Smith 1790, III.I.53).

The interconnected and relational nature should align the interests of the metaphorical person with society's interests; in cases when they may be in conflict, Smith is clear on the order in which their relative interests should be prioritised. 
Based on the above moral perspectives, we conclude that corporations have a key role to play in bringing about the economic prosperity of societies that they are connected with, and not just their shareholders. This provides a moral imperative for corporations to seek ways to resolve society's problems in ways that bring profit to it within the ethical boundaries of this moral framework. This requires commitment to strong business ethics and sound business decision-making processes to underpin its corporate citizenship (Roy 1999, p. 54).

The moral purpose of corporations as the enablers of societal prosperity, provides a 'push' over the barriers to market entry. A corporation that sees itself as connected to society places a value on societal returns such as improved human health and dignity, societal well-being, and public amenity, and counts non-monetary returns from social investments as additive to the monetary returns, consistent with strategic CSR. Thus the barrier that requires a particular rate of return on investment is effectively lowered when all of the return is not required to be financial. Governments can play a key role in reducing the risk for corporations at the initial stages of a fledgling industry, through initiatives such as investing in distributed sanitation infrastructure themselves and providing third party access to corporations. The societal taboos associated with sanitation may also be overcome through the moral imperatives, drawing new actors to this essential service that underpins public health, human dignity and environmental resource protection.

\section{CONCLUSIONS}

Adequate sanitation is essential for meeting the human right to a standard of living consistent with dignity and health, and to maintain the capacity for future generations to have access to clean water resources and healthy ecosystems. Existing institutional arrangements in developing Asian countries have not adequately facilitated the technologies or social behaviors needed for adequate sanitation. In industrialised countries, the developments in sanitation have traversed through a series of stages, from unmanaged to centralised and neo-centralised stages and the fledgling emergent stage. We have challenged the assumption that developing countries should follow a trajectory that parallels developments in industrialised countries, because their relative circumstances are quite different. Instead, the lack of existing investment in sanitation infrastructure in developing Asian countries may be viewed in a positive light, as an opportunity for these countries to 'leap frog' to the leading edge of both applied scientific knowledge, and technological and institutional arrangements that are adaptive and resilient to meet current needs and respond to risks in ways that are consistent with sustainability, providing better economic, ecological and social outcomes.

We have argued that business has a key role to play, and that there are opportunities for diverse businesses in leap frogging to this emergent stage. The Corporate Social Responsibility discourse offers a bridge between the profit motives of market economics and the social and ecological effects, including human rights, that have been neglected in the market economy as manifested. The commitment to corporate citizenship and social accountability founded on strong business ethics and sound business decision-making 
processes, has the potential to provide the necessary 'push' and 'pull' factors for the successful participation of businesses in meeting the human right to sanitation.

The CSR discourse may be strengthened by a broad acknowledgement of the relationship between business and society. Businesses are not natural entities but are given 'substance' through the legal and social context in which they are created. Thus, they are co-constituents of their social context and the network of relationships it comprises. Building on this relational view is crucial for the involvement of businesses in the delivery of sanitation - both in capturing the benefits and overcoming the barriers.

Moral codes and social norms can be effective in achieving conduct that is consistent with society's values and needs. We have argued that a moral code on the basis of Buddhist economics could guide managers of businesses to shape the conduct of the businesses they manage in ways that meet social values and needs while remaining profitable. Adherence to a moral code has the potential to achieve goals that go beyond the minimum demanded by the law, to display conduct that goes 'beyond compliance'.

An orientation of corporate citizenship founded upon a relational view of themselves and a moral code could catalyse businesses to take these opportunities and calculated risks for the benefit of themselves, the public and the environment.

\section{References}

Abeysuriya, K., Mitchell, C. \& Willetts, J., 2005. Cost Recovery for Urban Sanitation in Asian countries: insurmountable barrier or opportunity for sustainability? 2005 Conference of the Australia New Zealand Society for Ecological Economics (ANZSEE), Palmerston North, New Zealand.

Alvey, J.E., 2000. An introduction to economics as a moral science. International Journal of Social Economics, vol. 27, no. 12, pp. 1231-1252.

Alvey, J.E., 2003. Adam Smith's Globilization (But Anti-Secularization) Theory. Department of Applied and International Economics Discussion Paper No. 03.06, Massey University, <http://econ.massey.ac.nz/publications/discuss/dp03.06.pdf >.

Bakan, J., 2005. The Corporation : The Pathological Pursuit of Profit and Power. Free Press, New York.

Bakker, K.J., 2001. Paying for Water: water pricing and equity in England and Wales. Transactions of the Institute of British Geographers, vol. 26, pp. 143-164.

Berry, T., Campbell, S., Riedy, C. \& White, S., 2004. Discussion Paper: A New Distributed Infrastructure and Services Market: Assessing Australia's Future Market Potential. Institute for Sustainable Futures, Sydney.

Biswas, A.K., Tortajada, C., Lundqvist, J. \& Varis, O., 2004. The Water Challenges of Megacities. Water Front, June 2004, <http://www.siwi.org/downloads/WF\%20Magazine/Water_Front_June_2004.pdf $\geq$.

Bowie, $\vec{N}$., 1991. New Directions in Corporate Social Responsibility. Business Horizons, vol. 34, no. 4, pp. 56-65. 
Brown, P., 2003. World sewage plans should be abandoned. The Guardian, UK, $<$ http://www.guardian.co.uk/international/story/0,3604,910998,00.html $>$.

Czemiel, J., 2000. Phosphorus and nitrogen in sanitary systems in Kalmar. Urban Water, vol. 2, no. 1, pp. 63-69.

Daly, H.E., 1990. Toward some operational principles of sustainable development. Ecological Economics, vol. 2, no. 1, pp. 1-6.

Daniels, P.L., 2003. Buddhist economics and the environment: Material flow analysis and the moderation of society's metabolism. International Journal of Social Economics, vol. 30, no. 1/2, pp. 8-33.

Dasgupta, P., 1997. Environmental and Resource Economics in the World of the Poor. Resources for the Future, Washington DC.

Dietzmann, E.M. \& Gross, M.A., 2003. Phelps County Update: Case Study of a Public Water Supply District Providing Centralized Management of Decentralized Wastewater. Small Flows Quarterly, pp. 25-34 $<$ http://www.nesc.wvu.edu/nsfc/nsfc_sfq.htm>.

Donaldson, T. \& Preston, L.E., 1995. The Stakeholder Theory of the Corporation: concepts, evidence and implications. Academy of Management Review, vol. 20, no. 1 , pp. 65-91.

Dunn, C.P., 1991. Are corporations inherently wicked? Business Horizons, vol. 34, no. 4, pp. 3-8.

Estache, A. \& Rossi, M.A., 2002. How different is the efficiency of public and private water companies in Asia? The World Bank Economic Review, vol. 16, no. 1, pp. 139-148.

Evans, B., 2005. Securing Sanitation: The Compelling Case to Address the Crisis. Stockholm International Water Institute, with World Health Organisation and Norwegian Agency for Development Cooperation, www.siwi.org/downloads/Reports/CSD_Sanitation.pdf.

Fane, S.A. \& White, S.B., 2001. What are the Implications of Distributed Wastewater Management in Inner Sydney? International Ecological Engineering Conference, Lincoln University, New Zealand.

Feacham, R.G., Bradley, D.J., Garelick, H. \& Mara, D.D., 1983. Sanitation and disease : health aspects of excreta and wastewater management. Chichester [West Sussex] ; New York : Published for the World Bank by Wiley.

Fittschen, I. \& Niemczynowicz, J., 1997. Experiences with Dry Sanitation and Greywater Treatment in the Ecovillage Toarp, Sweden. Water Science \& Technology, vol. 35, no. 9, pp. 161-170.

Flyvbjerg, B., Rothengatter, W. \& Bruzelius, N., 2002. Megaprojects and risk : an anatomy of ambition. Cambridge University Press, New York.

Freeman, R.E. \& Liedtka, J., 1991. Corporate social responsibility: A critical approach. Business Horizons, vol. 34, no. 4, pp. 92-98.

Friedman, M., 1970. The Social Responsibility of Business is to Increase its Profits. New York Times Magazine, September 13, 1970, <http://lst-kieser.bwl.unimannheim.de/Downloads/SS05/Text_Friedman.pdf $>$.

Gas Research Institute, 1999. The Role of Distributed Generation in Competitive Electricity Markets. Distributed Generation Forum, http://www.distributedgeneration.com/Library/GRI_Role_of_DG.pdf. 
Goddard, N., 1996. "A mine of wealth"? The Victorians and the agricultural value of sewage. Journal of Historical Geography, vol. 22, no. 3, pp. 274-290.

Grusky, S. \& Fiil-Flynn, M., 2004. Will the World Bank Back Down? Water Privatization in a Climate of Global Protest. Public Citizen, http://www.citizen.org/documents/worldbank2004.pdf.

Gutierrez, E., Calaguas, B., Green, J. \& Roaf, V., 2003. New Rules, New Roles: Does PSP Benefit The Poor? WaterAid, http://www.wateraid.org.uk/site/in_depth/current_research/157.asp.

Hamilton, C., 2003. Growth fetish. Allen \& Unwin, Crows Nest, N.S.W.

Hanaeus, J., Hellstrom, D. \& Johansson, E., 1997. A Study of a Urine Separation System in an Ecological Village in Northern Sweden. Water Science \& Technology, vol. 35, no. 9, pp. 153-160.

Johnson \& Johnson, undated. Our Credo. $<$ http://www.jnj.com/our_company/our_credo/credo_heading.htm>.

Jones, T. \& Petrie, E., 2000. Spreading the Net - Distributed Power Generation and Creating a Virtual Utility to Manage It. ABB Review, pp. 13-21.

Kennedy, A.A., 2000. The End of Shareholder Value. Orion Business, London.

Kessides, I.N., 2004. Reforming Infrastructure: privatization, regulation and competition. World Bank.

Lawson, A., 2003. Future Lies in Traditional Latrines. viewed 13 March 2003 $<$ http://news.bbc.co.uk/go/pr/fr/-/1/hi/world/south_asia/2848215.stm>.

Lazonick, W. \& O'Sullivan, M., 2000. Maximizing shareholder value: a new ideology for corporate governance. Economy and Society, vol. 29, no. 1, pp. 13-35.

Lens, P., Zeeman, G. \& Lettinga, G. (eds), 2001. Decentralised Sanitation and Reuse Concepts, Systems and Implementation. IWA Publishing, Cornwall, UK.

Lobina, E. \& Hall, D., 1999. Public Sector Alternatives To Water Supply And Sewerage Privatisation: Case Studies. International Journal of Water Resources Development, Vol 16, No.1, 35-55, 2000, vol. 16, no. 1, pp. 35-55.

Lobina, E. \& Hall, D., 2001. UK Water privatisation - a briefing. Public Services International Research Unit, University of Greenwich.

Lovins, A.B., 2002. Small is profitable : the hidden economic benefits of making electrical resources the right size. Rocky Mountain Institute, Snowmass, Colorado.

McGranahan, G., Jacobi, P., Songsore, J., Surjadi, C. \& Kjellen, M., 2001. The Citizens at Risk : from Urban Sanitation to Sustainable Cities. Earthscan, London ; Sterling, VA.

Mitchell, C. \& Campbell, S., 2004. Synergy in the City: making the sum of the parts more than the whole. 2nd IWA Leading Edge Conference on Sustainability in Water Limited Environments, Sydney.

Mitchell, C. \& White, S., 2003. Forecasting and backcasting for sustainable urban water futures. Water, pp. 25-30.

Mulenga, M. \& Fawcett, B., 2003. Impediments to the Implementation of the DRA Methodology in Urban Sanitation Programmes in Zambia and South Africe. Alternative Water Forum, Bradford Centre for International Development, Bradford.

NDWRCDP, 2004. National Decentralized Water Resources Capacity Development Project. viewed May 2004 <http://www.ndwrcdp.org/>. 
Nelson, J. \& Prescott, D., 2003. Business and the Millennium Development Goals: A Framework for Action. International Business Leaders Forum and UNDP.

Nelson, J.A., 2004. Beyond Small-Is-Beautiful: A Buddhist and Feminist Analysis of Ethics and Business. Report Number 04-01, Global Development and Environment Institute, http://ase.tufts.edu/gdae/publications/working_papers/0401BeyondSmall.pdf.

Newman, P., 2001. Sustainable urban water systems in rich and poor cities--steps towards a new approach. Water Science And Technology, vol. 43, no. 4, pp. 93-99.

NWSDB, 2001. Feasibility Report on Provision of the Sewerage Infrasrtucture to Sri Jayawardanapura-Kotte. National Water Supply and Drainage Board.

Otterpohl, R., Grottker, M. \& Lange, J., 1997. Sustainable Water and Waste Management in Urban Areas. Water Science \& Technology, vol. 35, no. 9, pp. 121-133.

Payutto, P.A., 1992. Buddhist Economics: A Middle Way for the Market Place. $<$ http://www.urbandharma.org/udharma2/becono.html>.

Peet, J., 1992. Energy and the ecological economics of sustainability. Island Press, Washington, D.C.

Peter-Fröhlich, A., Kraume, I., Lesouëf, A. \& Oldenburg, M., 2003. Separate Discharge and Treatment of Urine, Faeces and Greywater Pilot Project. World Water \& Environmental Resources Congress, Philadelphia.

Pinkham, R., Hurley, E., Watkins, K., Lovins, A.B., Magliaro, J., Etnier, C. \& Nelson, V., 2004. Valuing Decentralized Wastewater Technologies: A Catalogue of Benefits, Costs and Economic Analysis Techniques. Rocky Mountains Institute, http://www.rmi.org/images/other/Water/W04-21_ValuWstWtr.pdf.

Porter, M.E. \& Kramer, M.R., 2002. The Competitive Advantage of Corporate Philanthropy. Harvard Business Review, vol. 80, no. 12, pp. 56-69.

Rahula, W., 1996. What the Buddha Taught. Buddhist Cultural Centre, Dehiwala, Sri Lanka.

Renzetti, S. \& Dupont, D., 2003. Ownership and Performance of Water Utilities. Greener Management International, vol. 42 Summer.

Roy, D., 1999. Corporate community involvement : philanthropy or self-interest? Charities Aid Foundation, West Mailing, England.

Saul, J.R., 2005. The Collapse of Globalism: and the Reinvention of the World. Penguin Group, Australia.

Schumacher, E.F., 1973. Small is Beautiful : Economics as if People Mattered.

Seppälä, O.T., Hukka, J.J. \& Katko, T.S., 2001. Public-Private Partnerships in Water and Sewerage Services: Privatization for Profit or Improvement of Service and Performance? Public Works Management \& Policy, vol. 6, no. 1, pp. 42-58.

Shofiani, N.E. \& Gustafsson, J.E., 2004. Privatisation of Municipal Waterworks and Sustainability of Water: A Case Study in Eastern Jakarta, Indonesia. 2nd IWA Leading Edge Conference on Sustainability in Water Limited Environments, Sydney.

SIWI, 2002. Corporate Responsibility to Facilitate Sustainablility in the Water Sector. Report Number 16, Stockholm International Water Institute, http://www.siwi.org/downloads/Reports/Report\%2016\%20\%20Founders\%20Sem inar\%202002.pdf.

SIWI, 2004. Report on the Seminar on Financing Water Infrastructure. Stockholm International Water Institute and World Bank, 
http://www.worldwatercouncil.org/fileadmin/Financing water for all/Stakeholde rs_responses/2004_WWW_SIWI_World_Bank_Seminar_Final_Report.pdf.

Smith, A., 1790. The Theory of Moral Sentiments. Sixth edition, Library of Economics and Liberty, viewed 23 November 2005 $<$ http://www.econlib.org/library/Smith/smMS.html>.

Smith, A., 1904. An Inquiry into the Nature and Causes of the Wealth of Nations. Methuen and Co., Ltd., Ed. Edwin Cannan, Library of Economics and Liberty, viewed 12 November 2005 $<$ http://www.econlib.org/library/Smith/smWN1.html>.

Smith, J.W., Lyons, G. \& Sauer-Thompson, G., 1999. The bankruptcy of economics : ecology, economics and the sustainability of the earth. Macmillan Press.

Söderbaum, P., 2003. Ecological economics for water policy and management: a need for major shifts in thinking. Water Science \& Technology, vol. 47, no. 6, pp. 33-41.

SustainAbility, 2004. Gearing up: from corporate responsibility to good governance. <http://www.positiveoutcomes.com.au/uploads/files/1098421105072_0.52066238 77156705.pdf $>$.

UN, 1948. Universal Declaration of Human Rights. United Nations, http://www.un.org/Overview/rights.html.

UN, 2005. What is the Global Compact? United Nations, viewed 20 November 2005 $<$ http://www.unglobalcompact.org/Portal/Default.asp?> .

Velasquez, M., 2003. Debunking Corporate Moral Responsibility. Business Ethics Quarterly, vol. 13, no. 4, pp. 531-562.

Weiser, J. \& Zadek, S., 2000. Conversations with Disbelievers. The Ford Foundation, http://216.65.35.60/pdf/convdisb.pdf.

West, S., 2003. Innovative On-site and Decentralised Sewage Treatment Reuse and Management Systems in Northern Europe \& the USA - Report of a study tour February to November 2000. http://www.watermagazine.com/secure/jc/sarah.pdf.

Wilderer, P.A. \& Schreff, D., 2000. Decentralized and centralized wastewater management: a challenge for technology developers. Water Science and Technology, vol. 41, no. 1, pp. 1-8.

Wilson, R., 2001. Corporation Social Responsibility: Putting the Words into Action. RIIA-MMSD Conference on Corporate Citizenship.

World Bank Group, 2004. Millennium Development Goals. viewed 25 November 2005 $<$ http://www.developmentgoals.org/Goals.htm>. 